\title{
Review
}

\section{The many faces of estrogen signaling}

\author{
Peter Vrtačnik, Barbara Ostanek, Simona Mencej-Bedrač, Janja Marc* \\ University of Ljubljana, Faculty of Pharmacy, Department of Clinical Biochemistry, Ljubljana, Slovenia \\ *Corresponding author: janja.marc@ffa.uni-lj.si
}

\begin{abstract}
Estrogens have long been known as important regulators of the female reproductive functions; however, our understanding of the role estrogens play in the human body has changed significantly over the past years. It is now commonly accepted that estrogens and androgens have important functions in both female and male physiology and pathology. This is in part due to the local synthesis and action of estrogens that broadens the role of estrogen signaling beyond that of the endocrine system. Furthermore, there are several different mechanisms through which the three estrogen receptors (ERs), ERa, ERß and G protein-coupled estrogen receptor 1 (GPER1) are able to regulate target gene transcription. ERa and ER $\beta$ are mostly associated with the direct and indirect genomic signaling pathways that result in target gene expression. Membrane-bound GPER1 is on the other hand responsible for the rapid non-genomic actions of estrogens that activate various protein-kinase cascades. Estrogen signaling is also tightly connected with another important regulatory entity, i.e. epigenetic mechanisms. Posttranslational histone modifications, microRNAs (miRNAs) and DNA methylation have been shown to influence gene expression of ERs as well as being regulated by estrogen signaling. Moreover, several coregulators of estrogen signaling also exhibit chromatin-modifying activities further underlining the importance of epigenetic mechanisms in estrogen signaling. This review wishes to highlight the newer aspects of estrogen signaling that exceed its classical endocrine regulatory role, especially emphasizing its tight intertwinement with epigenetic mechanisms.
\end{abstract}

Key words: estrogen signaling; extragonadal synthesis; epigenetic mechanisms; miRNA; DNA methylation

\section{Introduction}

Estrogens are perceived manly as ovarian sex hormones responsible for cellular proliferation and growth of tissues related to reproduction. In premenopausal women ovaries represent by far the most important source of circulating estrogens, although during pregnancy, placenta also secrets significant amounts of estrogens into the circulation (1). In addition to the effects on the female reproductive functions, estrogens also play a significant role in the regulation of skeletal homeostasis, lipid and carbohydrate metabolism, electrolyte balance, skin physiology, the cardiovascular system and the central nervous system $(1,2)$. Due to this wide regulatory role, it is not surprising that estrogens also have an important function in male physiology and cannot be viewed solely as female sex hormones. Postmenopausal women, due to the decline in their ovary function, and men are largely dependent on local synthesis of estrogens in extragonadal target tissues. This local production of estrogens extends their signaling from endocrine to paracrine, autocrine and intracrine (3). The complexity is further increased by multiple mechanisms of estrogen signaling, namely the well established direct and indirect genomic signaling, the fast non-genomic actions of steroid hormones and ligand-independent signaling (4). Moreover, estrogen signaling is also tightly intertwined with epigenetic mechanisms which have been an important focus of research in recent years. Posttranslational histone modifications, microRNAs (miRNAs) and DNA methylation are im- 
portant regulators of gene expression acting both upstream and downstream from estrogen receptors (ERs). Certain coregulators of estrogen signaling are able to induce posttranslational changes to histone proteins and specific epigenetic changes are necessary for initiation of transcription. Furthermore, different pathologies, aging and environmental factors can potentially influence estrogen signaling and regulation through induction of epigenetic changes $(5,6)$. This review wishes to highlight additional aspects of estrogen signaling that exceed the classical concept of endocrine regulation and particularly point out the close relationship between estrogen signaling and epigenetic mechanisms.

\section{Distribution of estrogen synthesis in the human organism}

In addition to ovaries, several extragonadal tissues also produce estrogens. These include mesenchymal cells of the adipose tissue including that of the breast, osteoblasts and chondrocytes, aortic smooth muscle cells and vascular endothelium, as well as numerous parts of the brain (7). In contrast to the importance of ovaries in premenopausal women, in postmenopausal women and men extragonadal tissues represent both the predominant source of estrogen synthesis and the main site of estrogen action. Only estrogens that escape local metabolism can enter the circulation, sug- gesting that plasma levels of estrogens reflect rather than direct estrogen action in postmenopausal women and men (7). This was confirmed by several studies comparing tissue and plasma sex steroid concentrations. They showed that in postmenopausal women concentrations of estrogens in breast cancer and abdominal adipose tissue were several fold higher than in plasma (8-10). As a consequence, the levels of active steroid hormones in the circulation of postmenopausal women and men are probably of no significance in assessing their concentrations in individual extragonadal tissues (7). Sex- and menopause-based differences in estrogen synthesis are summarized in Table 1.

In contrast to ovaries, estrogen production in extragonadal tissues is dependent on the availability of $\mathrm{C}_{19}$ steroid precursors, namely testosterone, androstenedione, dehydroepiandrosterone (DHEA) and dehydroepiandrosterone sulfate (DHEAS). In target tissues, testosterone can be converted to either 5a-dihydrotestosterone (DHT), the principal ligand for androgen receptors, or to $17 \beta$-estradiol, the most potent of the estrogens. Similarly, although requiring several enzymatic reactions, $\mathrm{DH}$ EAS, DHEA and androstenedione can also be converted to $17 \beta$-estradiol or DHT (Figure 1). Distribution of the required enzymes varies in different extragonadal tissues, making the metabolism of $\mathrm{DH}$ EAS and DHEA tissue-specific. In plasma of postmenopausal women and men, DHEAS is by far the most abundant steroid precursor, followed by

TABLE 1. Summary of sex- and menopause-based differences in estrogen synthesis $(1,4,7,11,76)$.

\begin{tabular}{|c|c|c|c|}
\hline & Premenopausal women & Postmenopausal women & Men \\
\hline $\begin{array}{l}\text { Sources of circulating } \\
17 \beta \text {-estradiol }\end{array}$ & $\begin{array}{c}\text { ovaries } \\
\text { (around 95\%), } \\
\text { adrenal cortex } \\
\text { (around 5\%) }\end{array}$ & $\begin{array}{l}\text { extragonadal tissues } \\
\text { (close to } 100 \%)\end{array}$ & $\begin{array}{c}\text { extragonadal tissues } \\
\text { (close to 80\%), } \\
\text { testes } \\
\text { (around 20\%) }\end{array}$ \\
\hline Plasma levels of $17 \beta$-estradiol & $\begin{array}{l}0.11-2.20 \mathrm{nM} \text { (depending on } \\
\text { the phase of the cycle) }\end{array}$ & around $0.04 \mathrm{nM}$ & around $0.10 \mathrm{nM}$ \\
\hline $\begin{array}{l}\text { Intracrine formation of } 17 \beta \text {-estradiol } \\
\text { in extragonadal tissues }\end{array}$ & estimated at around $75 \%$ & estimated at around $100 \%$ & estimated at around $100 \%$ \\
\hline $\begin{array}{l}\text { Source molecules for } 17 \beta \text {-estradiol } \\
\text { synthesis }\end{array}$ & $\begin{array}{l}\text { blood-derived cholesterol } \\
\text { and acetyl coenzyme A }\end{array}$ & $\begin{array}{c}\text { testosterone, } \\
\text { androstenedione, } \\
\text { DHEA and DHEAS }\end{array}$ & $\begin{array}{c}\text { testosterone, } \\
\text { androstenedione, } \\
\text { DHEA and DHEAS }\end{array}$ \\
\hline
\end{tabular}

DHEA - dehydroepiandrosterone; DHEAS - dehydroepiandrosterone sulphate. 

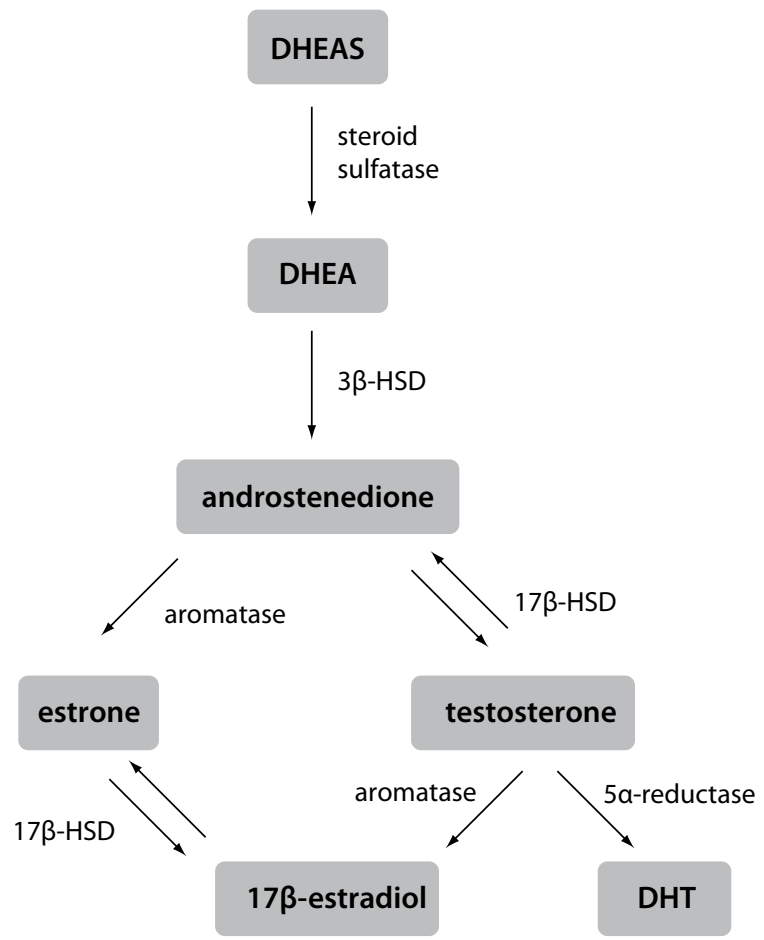

Figure 1. Schematic representation of estrogen synthesis in extragonadal tissues.

Estrogens and androgens are produced from $\mathrm{C}_{19}$ steroid precursors through several enzymatic conversions. Testosterone can be converted to the most active ligand on the androgen receptor, i.e. DHT, or the most active ligand on the estrogen receptor, i.e. $17 \beta$-estradiol, in a single reaction.

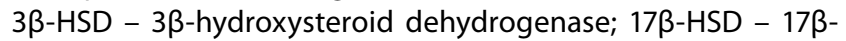
hydroxysteroid dehydrogenas; DHEA - dehydroepiandrosterone; DHEAS - dehydroepiandrosterone sulfate; DHT - 5adihydrotestosterone.

DHEA. Concentrations of both are several orders of magnitude greater than those of the active sex steroids, although their secretion and plasma concentrations decline significantly with advancing age. Interestingly, in postmenopausal women even the concentration of circulating testosterone exceeds that of $17 \beta$-estradiol by an order of magnitude. Approximately $25 \%$ of this testosterone is secreted directly from the ovaries, while the rest is formed in extragonadal tissues from steroid precursors. Androstenedione and DHEA are derived from both the adrenal cortex and the ovaries, whereas DHEAS is secreted entirely from the adrenals. The sheer amount of DHEAS and DHEA present in the circulation means they form a large reservoir of precursors available for the conversion to testosterone and estrogens in extragonadal tissues. Since testosterone can be converted in one reaction to either a ligand active at androgen receptor or a ligand active at estrogen receptors, it can be viewed as a circulating pro-hormone. Similar to the importance of estrogens in male physiology, high circulating concentrations of androgens indicate their significant role in women as well. In this light, it is impossible to separate estrogen signaling from androgen signaling or give them gender-specific roles. Therefore, it is always important to consider both regulatory pathways and their tight intertwinement in either women or men $(3,7,11)$. This fact only further accentuates the central role of extragonadal production of steroid hormones, for a long time an overlooked aspect of estrogen signaling.

\section{Structure and function of estrogen receptors}

Estrogens exert their effects by binding to their designated receptors. In spite of the importance of estrogen signaling there are only three known receptors that mediate all of the estrogens' effects. ERa was discovered first and is the most thoroughly investigated. Significantly homologues ER $\beta$ was identified almost four decades later and showed to have distinct, non-redundant roles (12). Another decade had to pass for the association of $G$ protein-coupled estrogen receptor 1 (GPER1) with estrogen signaling. Characteristics of all three receptors are summarized in Table 2.

$E R a$ has at least three and ER $\beta$ at least five different isoforms. Unlike the full length $E R a$, the two shorter ERa isoforms lack the N-terminal domain. Since they have the ability to heterodimerize with the full length ERa, they are able to repress ERa activity. The shortest ERa isoform termed ERa36, also acts as a membrane located ER able to interact with GPER1. The four shorter ER $\beta$ isoforms differ from the full length ER $\beta$ mostly in their ligandbinding domain, resulting in compromised ligandbinding ability. ER $\beta$ isoforms that are unable to bind ligands or coactivators and have no transcriptional activity dimerize preferentially with $E R a$, 
TABLE 2. Characteristics of estrogen receptors $(2,12-15,17,18,77)$.

\begin{tabular}{|c|c|c|c|}
\hline Receptor characteristic & ERa & ERß & GPER1 \\
\hline Receptor superfamily & \multicolumn{2}{|c|}{ nuclear steroid hormone receptor superfamily } & G-protein coupled receptor superfamily \\
\hline Type & \multicolumn{2}{|c|}{ nuclear } & membrane-bound G protein-coupled \\
\hline Structure & \multicolumn{2}{|c|}{$\begin{array}{l}\text { DNA-binding domain, } \\
\text { ligand-binding domain, N-terminal domain }\end{array}$} & $\begin{array}{l}7 \text { transmembrane a-helical regions, } 4 \\
\text { extracellular and } 4 \text { cytosolic segments }\end{array}$ \\
\hline Chromosome region & $6 q 25.1$ & $14 q 23.2$ & $7 p 22.3$ \\
\hline Number of isoforms & 3 & 5 & 1 \\
\hline Size & 595 aа & 530 aa & 375 aа \\
\hline $\begin{array}{l}\text { Distribution in human } \\
\text { tissues }\end{array}$ & $\begin{array}{c}\text { uterus, epididymis, } \\
\text { breast, liver, kidney, white } \\
\text { adipose tissue, prostate, } \\
\text { ovary, testes, skeleton, } \\
\text { brain }\end{array}$ & $\begin{array}{l}\text { colon, salivary gland, } \\
\text { vascular endothelium, } \\
\text { lung, bladder, prostate, } \\
\text { ovary, testes, skeleton, } \\
\text { brain }\end{array}$ & $\begin{array}{c}\text { central and peripheral nervous system, } \\
\text { uterus, ovaries, mammary glands, testes, } \\
\text { spermatogonial cells, gastrointestinal system, } \\
\text { pancreas, kidney, liver, adrenal and pituitary } \\
\text { glands, bone tissue, cardiovascular system, } \\
\text { immune cells }\end{array}$ \\
\hline Tamoxifen activity & partial agonist & antagonist & agonist \\
\hline
\end{tabular}

ER - estrogen receptor; GPER1 - G protein-coupled estrogen receptor 1; aa - amino acids.

thereby silencing ERa signaling. This indicates that different $E R a$ and $E R \beta$ isoforms can have a very diverse influence on estrogen signaling and target gene regulation $(13,14)$. Furthermore, relative concentrations of ERa and ER $\beta$ in a given cell significantly influence its response to various ligands. Homodimers of ERa and ER $\beta$ were shown to regulate largely different sets of genes from that of $E R a / \beta$ heterodimers. This is supported by the observation of completely distinct cellular responses by ER subtype-specific and non-specific agonists. It was also suggested that ER $\beta$ exerts an inhibitory effect on ERa-mediated signaling. Slightly different, in some instances even opposite, roles of ERa and ER $\beta$ are additionally underscored by differences in their expression in various tissues and organs (2).

GPER1, a plasma membrane receptor formerly known as an orphan $G$ protein-coupled receptor 30 (GPR30), is genetically and structurally unrelated to ERa and ER $\beta$. It is located on the cell surface and is responsible for rapid estrogen signaling, although certain ERa and ER $\beta$ variants have also been associated with the plasma membrane and the non-genomic signaling $(13,14)$. GPER1 functions and is expressed independently from the two ERs. It has high affinity, limited capacity, displaceable, single binding sites for estrogens. In comparison to nuclear ERs, its binding affinity for $17 \beta$-estradiol is considerably lower and the rates of association and dissociation are very rapid and completed within a few minutes. It displays largely similar ligand binding specificities to those of the nuclear ERs with certain distinct differences. The specificity of GPER1 for estrogens is also underlined by the fact, that other steroid hormones possess very low binding affinities for this receptor (15-17).

\section{Mechanisms of estrogen signaling}

Estrogen dependent signaling can be roughly divided into genomic and non-genomic, based on the outcome of cellular events, e.g. modulation of gene expression or activation of signaling cascades, respectively. Furthermore, binding of the estrogen-ER complex to DNA can be either direct or indirect. Different mechanisms of estrogen signaling are represented in Figure 2.

\section{Direct genomic signaling}

Direct genomic signaling pathway is considered as the classical mechanism of estrogen signaling. The binding of $17 \beta$-estradiol to ERa or ER $\beta$ in the cytoplasm of target cells causes conformational chang- 


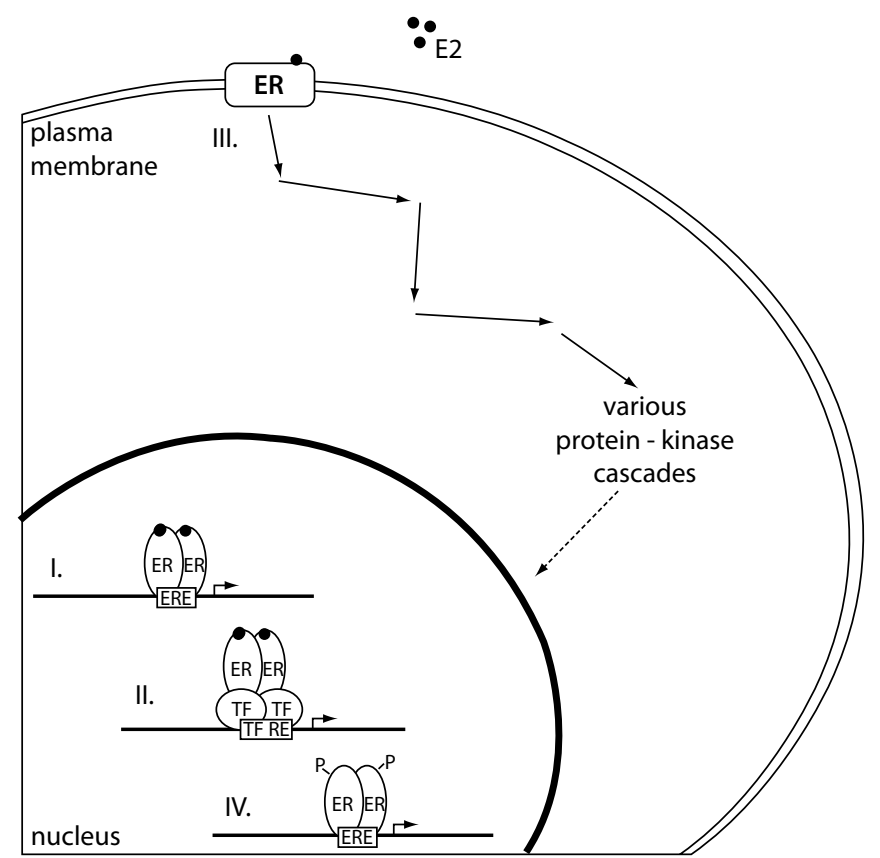

Figure 2. The representation of different mechanisms of estrogen signaling.

(I.) Direct genomic signaling pathway, considered the classical mechanism of estrogen signaling, promotes target gene expression by binding the E2-ER complex directly to the ERE. (II.) In the case of indirect genomic signaling pathway, E2-activated ERs bind DNA through protein-protein interactions with other classes of transcription factors at their respective response elements. (III.) Non-genomic signaling pathway starts with the binding of E2 to the ERs located at the plasma membrane resulting in the activation of various protein-kinase cascades. These can eventually lead to changes in gene expression due to phosphorylation of transcription factors. (IV). Ligand-independent signaling pathway causes ER activation and target gene transcription through phosphorylation of ERs or their associated coregulators.

E2 - 17 $\beta$-estradiol; ER - estrogen receptor; ERE - estrogen response element; $\mathrm{P}$ - phosphate group; TF - transcription factor; TF RE - transcription factor response element.

es that enable receptor dimerization, translocation to the nucleus and binding to the estrogen response elements (EREs) located in or near the promoters of target genes. Binding of the ligand to the receptor also triggers recruitment of a variety of coregulators in a complex that alters chromatin structure and facilitates recruitment of the RNA polymerase II transcriptional machinery. In this way, estrogen-ER complex acts as a transcriptional activator promoting gene expression (18).

\section{Indirect genomic signaling}

$17 \beta$-estradiol can also influence expression of genes that do not harbour EREs in their promoter regions. In fact, around one third of the estrogen responsive genes lack ERE-like sequences. In the case of ERE-independent genomic signaling ligand-activated ERs do not bind DNA directly, but rather through protein-protein interactions with other classes of transcription factors at their respective response elements. This mode of action enables activation or repression of target gene expression and significantly broadens estrogens regulatory influence. One of the best described examples includes interaction of estrogen-ER complex with FBJ murine osteosarcoma viral oncogene homolog (FOS) and jun proto-oncogene (JUN) proteins at the activator protein 1 (AP-1) binding sites in genes encoding ovalbumin, insulin-like growth factor 1 (IGF1), collagenase, cyclin D1 (CCND1) and choline acetyltransferase. The result depends on the ER subtype and type of the ligand. Other transcription factors that facilitate estrogen signaling also include Sp1 transcription factor, nuclear factor $\mathrm{KB}$ (NFKB), CCAAT/enhancer binding protein $\beta$ (C/EBP $\beta)$, GATA binding protein 1 (GATA1) and signal transducer and activator of transcription 5 (STAT5) (19).

\section{Non-genomic signaling}

It has been known for a long time that certain estrogen-induced changes are simply too rapid to be associated with target gene transcription and subsequent protein synthesis. Non-genomic actions are common to steroid hormones and are usually associated with the activation of various protein-kinase cascades that can eventually lead to indirect changes in gene expression due to phosphorylation of transcription factors. Non-genomic estrogen signaling is most often associated with a subset of membrane bound ER, e.g. GPER1 and certain variants of ERa and ER $\beta$. Binding of estrogens to ERs located at the cell surface can cause mobilization of intracellular calcium, stimulation of adenylate cyclase activity and cyclic adenosine monophosphate (CAMP) production, activation of the mitogen-activated protein kinase (MAPK) sign- 
aling pathway, activation of the phosphoinositol 3-kinase signaling pathway and activation of membrane tyrosine kinase receptors $(14,19)$. GPER1 is specifically associated with the stimulation of adenylate cyclase and activation of EGFR (15). Molecular mechanisms underlying non-genomic estrogen signaling are without a doubt diverse and numerous and may depend on a number of conditions, like the availability of signal transduction molecules and downstream targets, suggesting a cell type-specific mechanism.

\section{Ligand-independent signaling}

In addition to genomic and non-genomic liganddependent estrogen signaling, ERs can also be activated in the absence of $17 \beta$-estradiol or another suitable ligand. Phosphorylation of the receptors on certain residues or their associated coregulators can cause ligand-independent ER activation. The two most often targeted amino acids are serine and tyrosine. Signaling pathways responsible for this modulation include regulators of general cellular phosphorylation state, such as protein kinase $A(P K A)$ or protein kinase $C$ (PKC), extracellular signals such as peptide growth factors, cytokines or neurotransmitters and cell cycle regulators. Peptide growth factors represent especially important group of estrogen-independent ER activators that include epidermal growth factor (EGF), insulin, IGF1 and transforming growth factor $\beta$ (TGF $\beta$ ). Principle intermediates between growth factors and ERs are the guanine nucleotide-binding protein $\mathrm{p} 21^{\text {ras }}$ and MAPK phosphorylation cascades, among others. Additional extracellular signals that modulate ER activity include heregulin, interleukin 2 and dopamine, as well as regulatory proteins cyclin A and D1 (12).

It has become clear that the classic genomic mechanism contributes only a small part to the complexity of estrogen signaling. It is expected that $17 \beta$-estradiol is able to regulate expression of the same target gene through multiple mechanisms, both genomic and non-genomic. In addition, the same promoter sequence can harbour both ERE as well as response elements associated with other transcription factors. The final gene response therefore depends on multiple factors including combination of transcription factors present on the gene promoter, expression levels and cellular localization of all three ERs, their numerous coregulators, and signaling components, as well as the nature of the stimuli. Since these variables can differ significantly among various cell types, it is possible that estrogens use distinct signaling pathways depending on the cellular context and in this way ensure very precise and cell-specific regulation of target gene expression.

\section{Interactions of epigenetic mechanisms and estrogen signaling}

Estrogen signaling controls several physiological processes by directly and indirectly regulating target gene transcription. Another group of important gene expression regulators receiving a lot of attention in recent years consists of epigenetic mechanisms. These include posttranslational histone modifications, miRNA and DNA methylation and are characterized by their ability to influence gene expression without altering the DNA sequence in a stable and potentially heritable manner.

\section{Epigenetic mechanisms}

Perhaps the most complex of the three, histone proteins can be subjected to various posttranslational modifications including acetylation, methylation, phosphorylation, ubiquitination, deimination and sumoylation. They are usually restricted to lysine and arginine residues but can also occur on serine and threonine. High levels of acetylation and trimethylated lysine $(\mathrm{K})$ residue 4 of histone H3 (H3K4), H3K36 and H3K79 are associated with a more relaxed actively transcribed conformation of chromatin called euchromatin. Low levels of acetylation and high levels of H3K9, H3K27 and $\mathrm{H} 4 \mathrm{~K} 20$ methylation on the other hand result in a more condensed transcriptionally inactive heterochromatin. Most posttranslational histone modifications are dynamic and are regulated by families of enzymes that either bind or remove specific functional groups. For example, histone acetyltransferases (HATs) add, while histone deacetylases (HDACs) remove acetylation marks. Histone methyltransferases add methyl groups to arginine and 
lysine residues, while deiminases and lysine demethylases reverse these changes. There is also a similar relationship between histone kinases and phosphatases $(20,21)$.

miRNAs perform their regulatory role in a very different way. They are small, approximately $21 \mathrm{nu}$ cleotide-long, non-coding RNAs usually associated with target gene repression. They facilitate binding of the RNA-induced silencing complex (RISC) to the target mRNA, usually within its 3' UTR region. When miRNA sequence completely matches that of the target, mRNA is degraded. More often, miRNAs bind imperfectly to their targets, resulting in translational inhibition without mRNA cleavage. This can result in decreased target protein levels without any changes in the mRNA concentration. Individual miRNAs generally regulate multiple target genes at modest levels and many different miRNAs can target the same transcript (22).

Similar to miRNA-mediated posttranscriptional regulation, DNA methylation is mainly associated with gene repression. It is a reversible covalent binding of a single methyl group to the $5^{\prime}$ carbon of a cytosine residue located next to a guanosine. These dinucleotides commonly annotated as CpGs, occur with higher than expected frequency in regions referred to as $\mathrm{CpG}$ islands. These are unevenly distributed throughout the genome, located in promoter regions of genes, within genes and in intergenic locations. DNA methylation patterns are established by three DNA methyltransferases (DNMTs), namely DNMT1, DNMT3A and DNMT3B, and can be preserved during DNA replication and mitosis. This enables the inheritance of DNA methylation-mediated repression of target gene expression. The mechanisms of DNA demethylation which can be either passive or active are not yet fully elucidated (20).

\section{Coregulators of estrogen signaling}

As already mentioned, recruitment of a variety of coregulators in large multifunctional protein complexes is intrinsic to estrogen signaling. Most of these coregulators interact with many members of the nuclear receptor superfamily and are involved in chromatin remodeling, histone modifications, transcription initiation and elongation, splicing and proteasomal degradation. In addition to gene activation through coactivator recruitment, estrogen signaling is also associated with repression of transcription assisted by corepressors $(12,13)$. Coactivators associated with estrogen-mediated transcription include $\mathrm{v}$-src avian sarcoma (SchmidtRuppin A-2) viral oncogene homolog (SRC1), nuclear receptor coactivator 2 (NCOA2), NCOA3, proline, glutamate and leucine rich protein 1 (PELP1), CREB binding protein (CBP), E1A binding protein p300 (p300), K(lysine) acetyltransferase 2B (PCAF/ KAT2B), coactivator-associated arginine methyltransferase 1 (CARM1) and protein arginine methyltransferase 1 (PRMT1) while estrogen-induced repression recruits corepressors nuclear receptor corepressor 1 (NCOR1), NCOR2 and metastasis associated 1 (MTA1) among others (23). Even though coregulators are involved in a multitude of transcriptional steps we would like to point out their role as intermediates between transcriptional coregulation and epigenetic changes. A number of coregulators possess chromatin-modifying activities such as acetyltransferase and methyltransferase activity. In fact, histone acetylation is a necessary early step in transcription initiation marking active chromatin sites. Acetylation, as well as certain methylation marks attract additional transcriptional coactivators which in turn recruit general transcriptional machinery, including RNA polymerase and its accessory factors. The most commonly utilized HATs include p300, CBP, PCAF, KAT2A and KAT5. Conversely, removal of these acetylation marks from histones by corepressor complexes is associated with target gene silencing. Common HDACs include sirtuin 1 (SIRT1) and HDAC1-4 (24). Clearly chromatin modifications are integral to estrogen-mediated transcriptional regulation and gene expression in general.

\section{Epigenetic regulation of estrogen signaling}

Another contact point between estrogen signaling and epigenetic mechanisms is the epigenetic control of ER gene expression. Through the regulation of ER levels the epigenetic control extends to all ER target genes and estrogen-regulated processes. Several studies have shown that his- 
tone-modifying enzymes like, e.g. histone deacetylases HDAC1 and HDAC3 and histone methyltransferase suppressor of variegation 3-9 homolog 1 (Drosophila) (SUV39H1), are at least in part responsible for the reduction of ERa expression in oncological settings, specifically in breast cancer (2529). Conversely, histone deacetylase SIRT1 activity is necessary for $E R a$ expression in breast cancer. However, it was shown that SIRT1 is not directly associated with the ERa promoter and does not participate in histone modifications but is rather involved in the formation of basal transcription factor complexes at the ERa promoter. In addition, ERa and SIRT1 proteins directly interact to form transcriptional activator or repressor complexes depending on the targeted gene. This indicates that SIRT1 has other regulatory roles in addition to histone deacetylation $(29,30)$. The balance between HATs and HDACs present at ERa gene promoter was also pointed out as an important determinant of gene expression and repression. Furthermore, it was suggested that histone-modifying enzymes establish a more transient gene repression followed by the recruitment of DNMTs to the same regulatory complexes in order to methylate DNA for long-term gene silencing $(26,31)$. Despite the lack of data on direct associations between different histone modifications and $E R \beta$ gene expression, several studies reported re-expression of $E R \beta$ after treatment with trichostatin $A$ (TSA), an HDAC inhibitor, in breast, ovarian and prostate cancer cell lines. This effect was further increased when a DNMT inhibitor, 5-aza-2'-deoxycytidine (5-AZA), was added to the TSA treatment (32-35). This supports the observed complementary roles of histone deacetylation and DNA methylation in repressing gene expression. An increase in $E R \beta$ expression was also observed in a non-oncological setting after exposure to sodium butyrate, another HDAC inhibitor (36).

Similarly, miRNAs were also identified as important regulators of ER gene expression. ERa was shown to be directly targeted by numerous miRNAs, including miR-18a, miR-22, and miR-206 (for a more comprehensive list see Table 3) (37-45). There is markedly less information available about miRNAs targeting $E R \beta$ and GPER1. So far only miR-92 was
TABLE 3. Experimentally validated miRNAs that directly regulate ER gene expression.

\begin{tabular}{ccc}
\hline miRNA & Target gene & References \\
\hline miR-18a & & \\
miR-18b & & \\
miR-19a & & \\
miR-19b & & \\
miR-20b & & \\
miR-22 & & \\
miR-130a & & \\
miR-193b & ERa & \\
miR-206 & & \\
miR-221 & & \\
miR-222 & & \\
miR-302c & & \\
let-7a & & \\
let-7b & & \\
let-7i & & \\
miR-92 & & \\
\hline
\end{tabular}

miRNA - microRNA; ER - estrogen receptor.

identified as a miRNA that directly targets $E R \beta$, while no such miRNAs are known for GPER1 $(22,46)$.

DNA methylation is probably the most thoroughly analyzed epigenetic mechanism responsible for ER silencing in numerous malignancies. As already indicated, expression of several $E R a$ and $E R \beta$ isoforms was shown to be inversely correlated with the methylation of $\mathrm{CpGs}$ at their respective promoters. This association was observed repeatedly in multiple cell lines, primary cell cultures and tissue samples of hematopoietic neoplasms, endometrial, prostate, breast, and ovarian cancers, among others (47-53).

Even though the described studies focused mainly on epigenetic changes that resulted in ER silencing in numerous malignancies, they prove beyond a reasonable doubt that epigenetic mechanisms play an important role in the regulation of ER expression and consequently in the regulation of estrogen signaling.

\section{Estrogen-mediated control of epigenetic mechanisms}

The classic view of estrogen receptors as transcription factors suggests that the roles of estrogen sig- 
naling and epigenetic regulation can also be reversed, meaning that estrogen signaling is also able to regulate expression of certain chromatinmodifying enzymes and miRNAs (54).

An in vivo study showed a stimulatory effect of estrogen replacement on SIRT1 protein levels in bone marrow of estrogen-deficient mice (55). Activation of SIRT1 transcription by $17 \beta$-estradiol through ERa was also shown in breast cancer cell lines (29). Similarly, HDAC6 expression is also positively regulated by estrogen signaling (56). Furthermore, a transcriptome profiling study in primary osteoblasts identified lysine (K)-specific methyltransferase 2D (MLL2) as an estrogen-responsive gene (57). These examples clearly show that estrogen signaling plays an important role in the regulation of certain histone-modifying enzymes.

$17 \beta$-estradiol also significantly upregulates and downregulates expression of numerous miRNAs. All three ERs were shown to directly and indirectly influence transcription of miRNAs in tumorous and normal cells. ERa-mediated estrogen signaling inhibits transcription of miR-21, miR-26a, miR-140, miR-181b and miR-206, while it stimulates expression of miR-190a, miR-191, miR-203 and miR-425 among others $(37,58-63)$. ER $\beta$ is on the other hand associated with downregulation of miR-17, miR30a, miR-200a and miR-200b, and upregulation of miR-23b, miR-24-1 and miR-27b among others (64, $65)$. Additionally, binding of $17 \beta$-estradiol specifically to GPER1 was shown to repress the expression of miR-338-3p (66). A more comprehensive list of ER-regulated miRNAs is presented in Table 4.

As mentioned earlier, DNMTs are responsible for maintenance and de novo methylation of DNA. Estrogen signaling was clearly shown to influence the expression of DNMTs, although the results are quite diverse. DNMT1 was shown to be either downregulated or unaffected by $17 \beta$-estradiol, DNMT3A was downregulated, upregulated or unaffected in the same conditions, while DNMT3B could be downregulated or upregulated. There are many potential explanations for this discordance, the most obvious being differences between various malignant and non-malignant cell lines used by researchers, differences in their ER levels and
TABLE 4. ER-mediated regulation of miRNA expression.

\begin{tabular}{|c|c|c|c|}
\hline $\begin{array}{l}\text { Type of } \\
\text { ER-mediated } \\
\text { regulation } \\
\text { of miRNA } \\
\text { expression }\end{array}$ & \multicolumn{2}{|c|}{ miRNA } & References \\
\hline $\begin{array}{l}\text { ERa-mediated } \\
\text { downregulation }\end{array}$ & $\begin{array}{c}\text { let-7g } \\
\text { miR-16 } \\
\text { miR-21 } \\
\text { miR-23a } \\
\text { miR-26a } \\
\text { miR-26b } \\
\text { miR-27a } \\
\text { miR-34b } \\
\text { miR-107 } \\
\text { miR-125a } \\
\text { miR-140 } \\
\text { miR-143 }\end{array}$ & $\begin{array}{c}\text { miR-145 } \\
\text { miR-181b } \\
\text { miR-181c } \\
\text { miR-195 } \\
\text { miR-203 } \\
\text { miR-206 } \\
\text { miR-221 } \\
\text { miR-222 } \\
\text { miR-515-5p } \\
\text { miR-570 } \\
\text { miR-618 }\end{array}$ & $\begin{array}{l}(37,42,58 \\
59,78-85)\end{array}$ \\
\hline $\begin{array}{l}\text { ERa-mediated } \\
\text { upregulation }\end{array}$ & $\begin{array}{c}\text { miR-19a } \\
\text { miR-19b } \\
\text { miR-20a } \\
\text { miR-20b } \\
\text { miR-25 } \\
\text { miR-101 } \\
\text { miR-135a } \\
\text { miR-190a }\end{array}$ & $\begin{array}{c}\text { miR-191 } \\
\text { miR-196a2 } \\
\text { miR-203 } \\
\text { miR-424 } \\
\text { miR-425 } \\
\text { miR-760 } \\
\text { miR-942 } \\
\text { miR-944 }\end{array}$ & $\begin{array}{c}(42,60-62,78, \\
79,86,87)\end{array}$ \\
\hline $\begin{array}{l}\text { ER } \beta \text {-mediated } \\
\text { downregulation }\end{array}$ & $\begin{array}{c}\text { miR-9 } \\
\text { miR-9-3 } \\
\text { miR-17 } \\
\text { miR-18a } \\
\text { miR-18b } \\
\text { miR-19a } \\
\text { miR-19b } \\
\text { miR-20a } \\
\text { miR-20b } \\
\text { miR-21 } \\
\text { miR-24 } \\
\text { miR-25 } \\
\text { miR-27b } \\
\text { miR-30a } \\
\text { miR-30b } \\
\text { miR-31 }\end{array}$ & $\begin{array}{c}\text { miR-92a } \\
\text { miR-106a } \\
\text { miR-135a } \\
\text { miR-135b } \\
\text { miR-140-5p } \\
\text { miR-142-3p } \\
\text { miR-155 } \\
\text { miR-183 } \\
\text { miR-192 } \\
\text { miR-194 } \\
\text { miR-196a } \\
\text { miR-200a } \\
\text { miR-200b } \\
\text { miR-221 } \\
\text { miR-301a } \\
\text { miR-590-5p }\end{array}$ & $\begin{array}{l}(64,65 \\
88,89)\end{array}$ \\
\hline $\begin{array}{l}\text { ER } \beta \text {-mediated } \\
\text { upregulation }\end{array}$ & $\begin{array}{l}\text { miR-10a } \\
\text { miR-10b } \\
\text { miR-23b } \\
\text { miR-24-1 }\end{array}$ & $\begin{array}{l}\text { miR-27b } \\
\text { miR-191 } \\
\text { miR-205 }\end{array}$ & $(64,65,87)$ \\
\hline $\begin{array}{c}\text { ERa and/or } \\
\text { ERß-mediated } \\
\text { downregulation }\end{array}$ & $\begin{array}{c}\text { let-7e } \\
\text { miR-23b } \\
\text { miR-27b } \\
\text { miR-30c } \\
\text { miR-125b } \\
\text { miR-126 }\end{array}$ & $\begin{array}{c}\text { miR-146a } \\
\text { miR-181a } \\
\text { miR-200c } \\
\text { miR-204 } \\
\text { miR-208 } \\
\text { miR-429 }\end{array}$ & $\begin{array}{l}(60,63 \\
90-92)\end{array}$ \\
\hline $\begin{array}{l}\text { ERa and/or } \\
\text { ERß-mediated } \\
\text { upregulation }\end{array}$ & $\begin{array}{l}\text { let-7a } \\
\text { let-7b } \\
\text { let-7c } \\
\text { let-7d }\end{array}$ & $\begin{array}{l}\text { miR-98 } \\
\text { miR-106a } \\
\text { miR-128a } \\
\text { miR-130b }\end{array}$ & $\begin{array}{c}(60,90,91 \\
93-98)\end{array}$ \\
\hline
\end{tabular}




\begin{tabular}{cccc}
\hline & let-7e & miR-148a & \\
& let-7f & miR-155 & \\
& let-7g & miR-182 & \\
ERa and/or & let-7i & miR-200b & \\
ER 3 -mediated & miR-7 & miR-205 & $(60,90,91$, \\
upregulation & miR-17 & miR-223 & 93-98) \\
& miR-18a & miR-320 & \\
& miR-21 & miR-451 & \\
& miR-27a & miR-486 & \\
& miR-92a-1 & miR-708 & \\
\hline
\end{tabular}

GPER1-mediated downregulation miR-338-3p

Only miRNAs that where validated and thoroughly studied in individual references are included in the list.

ER - estrogen receptor; miRNA - microRNA; GPER1 - G protein-coupled estrogen receptor 1.

differences in the signaling coregulators present (14,67-72). In line with this, studies observed that estrogen signaling either increased DNA methylation and subsequently epigenetically silenced target genes or predominantly demethylated DNA resulting in epigenetic upregulation of downstream targets $(31,67,68,73)$. Furthermore, developmental exposure to relevant doses of $17 \beta$-estradiol or xenoestrogens induced hypomethylation of certain and hypermethylation of other genes, increasing the susceptibility to certain types of adultonset cancer $(72,74,75)$.

Estrogen signaling end epigenetic regulation are two ubiquitous regulatory mechanisms essential for maintaining cell and tissue homeostasis. Due to their importance it is not surprising that their functions tightly intertwine. In addition, their complementary roles increase the level of cell-specificity and fine-tuning of transcriptional regulation.

\section{Conclusions}

In the last two decades, we saw a dramatic increase in our understanding of estrogen signaling.
Extragonadal synthesis of estrogens and their tight connection with androgens have extended the mechanism of estrogen action from endocrine to paracrine, autocrine and even intracrine signaling. Estrogens and androgens have lost their genderlimited roles importantly contributing to the physiology of several tissues and organ systems. Furthermore, at least three different estrogen receptors, namely ERa, ER $\beta$ and GPER1, with distinct, non-redundant and in certain cases opposite roles are now known. Indirect genomic signaling through the interactions with other transcription factors at their DNA response elements and the fast non-genomic signaling mediated by membrane-bound ERs additionally increase the complexity of estrogen signaling. Importantly, estrogen signaling is also tightly connected to epigenetic mechanisms both as the regulator of gene expression of certain chromatin-modifying enzymes and miRNAs, as well as their target through the epigenetic regulation of ER gene expression levels. Moreover, certain epigenetic changes are intrinsic to estrogen-mediated transcriptional regulation and are executed at least in part by coregulators of estrogen signaling. Epigenetic mechanisms thus augment not only the intricacy but also the specificity and fine-tuning of estrogen-mediated transcriptional control. Better comprehension of the complexity of estrogen regulation has deepened our understanding of the effects of the existing estrogen receptor modulators as well as opened opportunities for the discovery of new tissue- and perhaps even cell-specific compounds.

\section{Acknowledgments}

This work was supported by the Slovenian Research Agency (grants ARMR19, P3-0298, J3-2330 and J3-5511).

\section{Potential conflict of interest}

None declared. 


\section{References}

1. Hall JE. Guyton and Hall textbook of medical physiology. 12th ed. Philadelphia, PA: Saunders/Elsevier, 2011.

2. Nilsson S, Gustafsson J. Estrogen receptors: therapies targeted to receptor subtypes. Clin Pharmacol Ther 2011;89:4455. http://dx.doi.org/10.1038/clpt.2010.226.

3. Labrie F. Extragonadal synthesis of sex steroids: intracrinology. Ann Endocrinol (Paris) 2003;64:95-107.

4. Venken K, Boonen S, Bouillon R, Vanderschueren D. Chapter 24. Gonadal Steroids. In: Rosen CJ, ed. Primer on the metabolic bone diseases and disorders of mineral metabolism. 7th ed. Washington: ASBMR; 2009. p. 117-23.

5. Gallou-Kabani C, Vige A, Gross MS, Junien C. Nutri-epigenomics: lifelong remodelling of our epigenomes by nutritional and metabolic factors and beyond. Clin Chem Lab Med 2007;45:321-7. http://dx.doi.org/10.1515/CCLM.2007.081.

6. Kuhlmann JD, Rasch J, Wimberger P, Kasimir-Bauer S. miCroRNA and the pathogenesis of ovarian cancer-a new horizon for molecular diagnostics and treatment? Clin Chem Lab Med 2012;50:601-15.

7. Simpson ER. Sources of estrogen and their importance. $J$ Steroid Biochem Mol Biol 2003;86:225-30. http://dx.doi. org/10.1016/S0960-0760(03)00360-1.

8. Szymczak J, Milewicz A, Thijssen JH, Blankenstein MA, Daroszewski J. Concentration of sex steroids in adipose tissue after menopause. Steroids 1998;63:319-21. http://dx.doi. org/10.1016/S0039-128X(98)00019-1.

9. Blankenstein MA, van de Ven J, Maitimu-Smeele I, Donker GH, de Jong PC, Daroszewski J, et al. Intratumoral levels of estrogens in breast cancer. J Steroid Biochem Mol Biol 1999;69:293-7. http://dx.doi.org/10.1016/S0960-0760(99)00048-5.

10. Mady EA, Ramadan EE, Ossman AA. Sex steroid hormones in serum and tissue of benign and malignant breast tumor patients. Dis Markers 2000;16:151-7. http://dx.doi. org/10.1155/2000/305940.

11. Labrie F. Intracrinology. Mol CellEndocrinol 1991;78:C113-8. http://dx.doi.org/10.1016/0303-7207(91)90116-A.

12. Nilsson S, Mäkelä S, Treuter E, Tujague M, Thomsen J, Andersson $G$, et al. Mechanisms of estrogen action. Physiol Rev 2001;81:1535-65.

13. Heldring N, Pike A, Andersson S, Matthews J, Cheng G, Hartman J, et al. Estrogen receptors: how do they signal and what are their targets. Physiol Rev 2007;87:905-31. http:// dx.doi.org/10.1152/physrev.00026.2006.

14. Ajj H, Chesnel A, Pinel S, Plenat F, Flament S, Dumond H. An alkylphenol mix promotes seminoma derived cell proliferation through an ERalpha36-mediated mechanism. PLoS One 2013;8:e61758. http://dx.doi.org/10.1371/journal.pone.0061758.

15. Filardo EJ, Thomas P. Minireview: G protein-coupled estrogen receptor-1, GPER-1: its mechanism of action and role in female reproductive cancer, renal and vascular physiology. Endocrinology 2012;153:2953-62. http://dx.doi. org/10.1210/en.2012-1061.

16. Filardo E, Quinn J, Pang Y, Graeber C, Shaw S, Dong J, et al. Activation of the novel estrogen receptor $G$ protein-coupled receptor 30 (GPR30) at the plasma membrane. Endocrinology 2007;148:3236-45. http://dx.doi.org/10.1210/en.20061605.
17. Sandén C, Broselid S, Cornmark L, Andersson K, DaszkiewiCz-Nilsson J, Mårtensson UE, et al. G protein-coupled estrogen receptor $1 / G$ protein-coupled receptor 30 localizes in the plasma membrane and traffics intracellularly on cytokeratin intermediate filaments. Mol Pharmacol 2011;79:40010. $h t t p: / / d x$. doi.org/10.1124/mol.110.069500.

18. Lodish H, Berk A, Kaiser CA, Krieger M, Scott MP, Bretscher $A$, et al. Molecular cell biology. 6th ed. New York: W.H. Freeman and Company; 2008.

19. Björnström L, Sjöberg M. Mechanisms of estrogen receptor signaling: convergence of genomic and nongenomic actions on target genes. Mol Endocrinol 2005;19:833-42. http://dx.doi.org/10.1210/me.2004-0486.

20. Gibney ER, Nolan CM. Epigenetics and gene expression. Heredity (Edinb) 2010;105:4-13. http://dx.doi.org/10.1038/ hdy.2010.54.

21. Portela A, Esteller M. Epigenetic modifications and human disease. Nat Biotechnol 2010;28:1057-68. http://dx.doi. org/10.1038/nbt.1685.

22. Klinge CM. miRNAs and estrogen action. Trends Endocrinol Metab 2012;23:223-33. http://dx.doi.org/10.1016/j. tem.2012.03.002.

23. Mann M, Cortez V, Vadlamudi RK. Epigenetics of Estrogen Receptor Signaling: Role in Hormonal Cancer Progression and Therapy. Cancers (Basel) 2011;3:1691-707. http:// dx.doi.org/10.3390/cancers3021691.

24. Bulynko YA, O'Malley BW. Nuclear receptor coactivators: structural and functional biochemistry. Biochemistry 2011;50:313-28. http://dx.doi.org/10.1021/bi101762x.

25. Kawai H, Li H, Avraham S, Jiang S, Avraham HK. Overexpression of histone deacetylase HDAC1 modulates breast cancer progression by negative regulation of estrogen receptor alpha. Int J Cancer 2003;107:353-8. http://dx.doi. org/10.1002/ijc. 11403.

26. Macaluso M, Cinti C, Russo G, Russo A, Giordano A. pRb2/ p130-E2F4/5-HDAC1-SUV39H1-p300 and pRb2/p130E2F4/5-HDAC1-SUV39H1-DNMT1 multimolecular complexes mediate the transcription of estrogen receptor-alpha in breast cancer. Oncogene 2003;22:3511-7. http:// dx.doi.org/10.1038/sj.onc. 1206578.

27. Woodfield GW, Hitchler MJ, Chen Y, Domann FE, Weigel RJ. Interaction of TFAP2C with the estrogen receptor-alpha promoter is controlled by chromatin structure. Clin Cancer Res 2009;15:3672-9. http://dx.doi.org/10.1158/1078-0432. CCR-08-2343.

28. Hostetter CL, Licata LA, Keen JC. Timing is everything: order of administration of 5-aza 2' deoxycytidine, trichostatin A and tamoxifen changes estrogen receptor $m R N A$ expression and cell sensitivity. Cancer Lett 2009;275:178-84. http:// dx.doi.org/10.1016/j.canlet.2008.10.005.

29. Elangovan S, Ramachandran S, Venkatesan N, Ananth $S$, Gnana-Prakasam JP, Martin PM, et al. SIRT1 is essential for oncogenic signaling by estrogen/estrogen receptor $a$ in breast cancer. Cancer Res 2011;71:6654-64. http://dx.doi. org/10.1158/0008-5472.CAN-11-1446.

30. Yao Y, Li H, Gu Y, Davidson NE, Zhou Q. Inhibition of SIRT1 deacetylase suppresses estrogen receptor signaling. Carcinogenesis 2010;31:382-7. http://dx.doi.org/10.1093/carcin/bgp308. 
31. Leu YW, Yan PS, Fan M, Jin VX, Liu JC, Curran EM, et al. Loss of estrogen receptor signaling triggers epigenetic silencing of downstream targets in breast cancer. Cancer Res 2004;64:8184-92. http://dx.doi.org/10.1158/0008-5472. CAN-04-2045.

32. Walton TJ, Li G, Seth $R$, McArdle SE, Bishop MC, Rees $R C$. DNA demethylation and histone deacetylation inhibition co-operate to re-express estrogen receptor beta and induce apoptosis in prostate cancer cell-lines. Prostate 2008;68:210-22. http://dx.doi.org/10.1002/pros.20673.

33. Yap OW, Bhat G, Liu L, Tollefsbol TO. Epigenetic modifications of the Estrogen receptor beta gene in epithelial ovarian cancer cells. Anticancer Res 2009;29:139-44.

34. Tu Z, Li H, Ma Y, Tang B, Tian J, Akers W, et al. The enhanced antiproliferative response to combined treatment of trichostatin A with raloxifene in MCF-7 breast cancer cells and its relevance to estrogen receptor $\beta$ expression. Mol Cell Biochem 2012;366:111-22. http://dx.doi.org/10.1007/s11010012-1288-9.

35. Pitta CA, Papageorgis $P$, Charalambous $C$, Constantinou Al. Reversal of ER- $\beta$ silencing by chromatin modifying agents overrides acquired tamoxifen resistance. Cancer Lett 2013;337:167-76. http://dx.doi.org/10.1016/j. canlet.2013.05.031.

36. Stolzenberg DS, Stevens JS, Rissman EF. Experience-facilitated improvements in pup retrieval; evidence for an epigenetic effect. Horm Behav 2012;62:128-35. http://dx.doi. org/10.1016/j.yhbeh.2012.05.012.

37. Adams BD, Furneaux $H$, White BA. The micro-ribonucleic acid (miRNA) miR-206 targets the human estrogen receptor-alpha (ERalpha) and represses ERalpha messenger RNA and protein expression in breast cancer cell lines. Mol Endocrinol 2007;21:1132-47. http://dx.doi.org/10.1210/ me.2007-0022.

38. Zhao JJ, Lin J, Yang H, Kong W, He L, Ma X, et al. MicroRNA221/222 negatively regulates estrogen receptor alpha and is associated with tamoxifen resistance in breast cancer. $J$ Biol Chem 2008;283:31079-86. http://dx.doi.org/10.1074/ jbc.M806041200.

39. Liu WH, Yeh SH, Lu CC, Yu SL, Chen HY, Lin CY, et al. MicroRNA-18a prevents estrogen receptor-alpha expression, promoting proliferation of hepatocellular carcinoma cells. Gastroenterology 2009;136:683-93. http://dx.doi. org/10.1053/j.gastro.2008.10.029.

40. Leivonen SK, Mäkelä R, Ostling P, Kohonen P, Haapa-Paananen $S$, Kleivi $K$, et al. Protein lysate microarray analysis to identify microRNAs regulating estrogen receptor signaling in breast cancer cell lines. Oncogene 2009;28:3926-36. http://dx.doi.org/10.1038/onc.2009.241.

41. Pandey DP, Picard D. miR-22 inhibits estrogen signaling by directly targeting the estrogen receptor alpha $m R N A$. Mol Cell Biol 2009;29:3783-90. http://dx.doi.org/10.1128/ MCB.01875-08.

42. Castellano L, Giamas G, Jacob J, Coombes RC, Lucchesi W, Thiruchelvam $P$, et al. The estrogen receptor-alpha-induced microRNA signature regulates itself and its transcriptional response. Proc Natl Acad Sci U S A 2009;106:15732-7. http://dx.doi.org/10.1073/pnas.0906947106.
43. Loven J, Zinin N, Wahlstrom T, Muller I, Brodin P, Fredlund $E$, et al. MYCN-regulated microRNAs repress estrogen receptor-alpha (ESR1) expression and neuronal differentiation in human neuroblastoma. Proc Natl Acad Sci U S A 2010;107:1553-8. http://dx.doi.org/10.1073/ pnas.0913517107.

44. Zhao Y, Deng C, Wang J, Xiao J, Gatalica Z, Recker RR, et al. Let-7 family miRNAs regulate estrogen receptor alpha signaling in estrogen receptor positive breast cancer. Breast Cancer Res Treat 2011;127:69-80. http://dx.doi. org/10.1007/s10549-010-0972-2.

45. Tang $L, P u Y$, Wong DK, Liu T, Tang $H$, Xiang $T$, et al. The hepatitis $B$ virus-associated estrogen receptor alpha (ERalpha) was regulated by microRNA-130a in HepG2.2.15 human hepatocellular carcinoma cells. Acta Biochim Biophys Sin (Shanghai) 2011;43:640-6. http://dx.doi.org/10.1093/ abbs/gmr051.

46. Al-Nakhle $H$, Burns $P A$, Cummings $M$, Hanby AM, Hughes $T A$, Satheesha $S$, et al. Estrogen receptor \{beta\}1 expression is regulated by miR-92 in breast cancer. Cancer Res 2010;70:4778-84. http://dx.doi.org/10.1158/0008-5472. CAN-09-4104.

47. Issa JP, Zehnbauer BA, Civin Cl, Collector MI, Sharkis SJ, Davidson $N E$, et al. The estrogen receptor $C p G$ island is methylated in most hematopoietic neoplasms. Cancer Res 1996;56:973-77.

48. Sasaki M, Kotcherguina L, Dharia A, Fujimoto S, Dahiya $R$. Cytosine-phosphoguanine methylation of estrogen receptors in endometrial cancer. Cancer Res 2001;61:3262-6.

49. Sasaki M, Tanaka Y, Perinchery G, Dharia A, Kotcherguina I, Fujimoto $S$, et al. Methylation and inactivation of estrogen, progesterone, and androgen receptors in prostate cancer. $J$ Natl Cancer Inst 2002;94:384-90. http://dx.doi.org/10.1093/ jnci/94.5.384.

50. Zhao C, Lam EW, Sunters A, Enmark E, De Bella MT, Coombes $R C$, et al. Expression of estrogen receptor beta isoforms in normal breast epithelial cells and breast cancer: regulation by methylation. Oncogene 2003;22:7600-6. http:// dx.doi.org/10.1038/sj.onc. 1207100.

51. Zhu X, Leav I, Leung YK, Wu M, Liu Q, Gao Y, et al. Dynamic regulation of estrogen receptor-beta expression by DNA methylation during prostate cancer development and metastasis. Am J Pathol 2004;164:2003-12. http://dx.doi. org/10.1016/S0002-9440(10)63760-1.

52. Suzuki F, Akahira J, Miura I, Suzuki T, Ito K, Hayashi S, et al. Loss of estrogen receptor beta isoform expression and its correlation with aberrant DNA methylation of the 5'-untranslated region in human epithelial ovarian carcinoma. Cancer Sci 2008;99:2365-72. http://dx.doi.org/10.1111/ j.1349-7006.2008.00988.x.

53. Wei J, Han B, Mao XY, Wei MJ, Yao F, Jin F. Promoter methylation status and expression of estrogen receptor alpha in familial breast cancer patients. Tumour Biol 2012;33:413 20. http://dx.doi.org/10.1007/s13277-011-0234-x.

54. Cohen A, Shmoish M, Levi L, Cheruti U, Levavi-Sivan B, Lubzens E. Alterations in micro-ribonucleic acid expression profiles reveal a novel pathway for estrogen regulation. Endocrinology 2008;149:1687-96. http://dx.doi.org/10.1210/ en.2007-0969. 
55. Elbaz A, Rivas D, Duque G. Effect of estrogens on bone marrow adipogenesis and Sirt 1 in aging C57BL/6J mice. Biogerontology 2009;10:747-55. http://dx.doi.org/10.1007/ s10522-009-9221-7.

56. Saji S, Kawakami M, Hayashi S, Yoshida N, Hirose M, Horiguchi $S$, et al. Significance of HDAC6 regulation via estrogen signaling for cell motility and prognosis in estrogen receptor-positive breast cancer. Oncogene 2005;24:4531-9. http://dx.doi.org/10.1038/sj.onc.1208646.

57. Denger S, Bähr-Ivacevic T, Brand H, Reid G, Blake J, Seifert $M$, et al. Transcriptome profiling of estrogen-regulated genes in human primary osteoblasts reveals an osteoblastspecific regulation of the insulin-like growth factor binding protein 4 gene. Mol Endocrinol 2008;22:361-79. http:// dx.doi.org/10.1210/me.2007-0292.

58. Wickramasinghe NS, Manavalan TT, Dougherty SM, Riggs KA, Li Y, Klinge CM. Estradiol downregulates miR-21 expression and increases miR-21 target gene expression in MCF-7 breast cancer cells. Nucleic Acids Res 2009;37:258495. http://dx.doi.org/10.1093/nar/gkp117.

59. Zhang Y, Eades G, Yao Y, Li Q, Zhou Q. Estrogen receptor a signaling regulates breast tumor-initiating cells by downregulating miR-140 which targets the transcription factor SOX2. J Biol Chem 2012;287:41514-22. http://dx.doi. org/10.1074/jbc.M112.404871.

60. Zhao J, Imbrie GA, Baur WE, Iyer LK, Aronovitz MJ, Kershaw $T B$, et al. Estrogen receptor-mediated regulation of micro $R$ $N A$ inhibits proliferation of vascular smooth muscle ceIls. Arterioscler Thromb Vasc Biol 2013;33:257-65. http:// dx.doi.org/10.1161/ATVBAHA.112.300200.

61. Chu HW, Cheng CW, Chou WC, Hu LY, Wang HW, Hsiung CN, et al. A novel estrogen receptor-microRNA 190a-PAR-1-pathway regulates breast cancer progression, a finding initially suggested by genome-wide analysis of loci associated with lymph-node metastasis. Hum Mol Genet 2014;23:35567. http://dx.doi.org/10.1093/hmg/ddt426.

62. Di Leva G, Piovan C, Gasparini P, Ngankeu A, Taccioli $C$, Briskin D, et al. Estrogen mediated-activation of miR$191 / 425$ cluster modulates tumorigenicity of breast cancer cells depending on estrogen receptor status. PLoS Genet 2013;9:e1003311. http://dx.doi.org/10.1371/journal. pgen. 1003311.

63. Maillot G, Lacroix-Triki M, Pierredon S, Gratadou L, Schmidt $S$, Bénès $V$, et al. Widespread estrogen-dependent repression of micrornas involved in breast tumor cell growth. Cancer Res 2009;69:8332-40. http://dx.doi.org/10.1158/00085472.CAN-09-2206.

64. Paris $O$, Ferraro L, Grober OM, Ravo M, De Filippo MR, Giurato $G$, et al. Direct regulation of microRNA biogenesis and expression by estrogen receptor beta in hormone-responsive breast cancer. Oncogene 2012;31:4196-206. http:// dx.doi.org/10.1038/onc.2011.583.

65. Edvardsson K, Nguyen-Vu T, Kalasekar SM, Pontén F, Gustafsson J, Williams C. Estrogen receptor $\beta$ expression induces changes in the microRNA pool in human colon cancer cells. Carcinogenesis 2013;34:1431-41. http://dx.doi. org/10.1093/carcin/bgt067.
66. Jacovetti $C$, Abderrahmani A, Parnaud G, Jonas JC, Peyot $M L$, Cornu $M$, et al. MicroRNAs contribute to compensatory $\beta$ cell expansion during pregnancy and obesity. J Clin Invest 2012;122:3541-51. http://dx.doi.org/10.1172/JCI64151.

67. Zhai R, Wang G, Cai K, Tao K, Xu F, Zhang W, et al. Epigenetic regulation of the ERbeta gene on the estrogen signal transfection pathway in colon cancer cells. J Huazhong Univ Sci Technolog Med Sci 2010;30:69-74. http://dx.doi. org/10.1007/s11596-010-0112-6.

68. Kubarek $\measuredangle$, Jagodzinski PP. Epigenetic up-regulation of CXCR4 and CXCL12 expression by 17 beta-estradiol and tamoxifen is associated with formation of DNA methyltransferase 3B4 splice variant in Ishikawa endometrial adenocarcinoma cells. FEBS Lett 2007;581:1441-8. http://dx.doi. org/10.1016/j.febslet.2007.02.070.

69. Cui M, Wen Z, Yang Z, Chen J, Wang F. Estrogen regulates DNA methyltransferase 3B expression in Ishikawa endometrial adenocarcinoma cells. Mol Biol Rep 2009;36:2201-7. http://dx.doi.org/10.1007/s11033-008-9435-9.

70. Yamagata $Y$, Asada H, Tamura I, Lee L, Maekawa R, Taniguchi $K$, et al. DNA methyltransferase expression in the human endometrium: down-regulation by progesterone and estrogen. Hum Reprod 2009;24:1126-32. http://dx.doi. org/10.1093/humrep/dep015.

71. Logan PC, Ponnampalam AP, Steiner M, Mitchell MD. Effect of cyclic AMP and estrogen/progesterone on the transcription of DNA methyltransferases during the decidualization of human endometrial stromal cells. Mol Hum Reprod 2013;19:302-12. http://dx.doi.org/10.1093/molehr/gas062.

72. Chao HH, Zhang XF, Chen B, Pan B, Zhang LJ, Li L, et al. Bisphenol $A$ exposure modifies methylation of imprinted genes in mouse oocytes via the estrogen receptor signaling pathway. Histochem Cell Biol 2012;137:249-59. http://dx.doi. org/10.1007/s00418-011-0894-z.

73. Marques M, Laflamme L, Gaudreau L. Estrogen receptor a can selectively repress dioxin receptor-mediated gene expression by targeting DNA methylation. Nucleic Acids Res 2013;41:8094-106. http://dx.doi.org/10.1093/nar/gkt595.

74. Cheng AS, Culhane AC, Chan MW, Venkataramu CR, Ehrich $M$, Nasir $A$, et al. Epithelial progeny of estrogen-exposed breast progenitor cells display a cancer-like methylome. Cancer Res 2008;68:1786-96. http://dx.doi.org/10.1158/00085472.CAN-07-5547.

75. Ho SM, Tang WY, Belmonte de Frausto J, Prins GS. Developmental exposure to estradiol and bisphenol $A$ increases susceptibility to prostate carcinogenesis and epigenetically regulates phosphodiesterase type 4 variant 4 . Cancer Res 2006;66:5624-32. http://dx.doi.org/10.1158/0008-5472. CAN-06-0516.

76. Thomas L, ed. Clinical laboratory diagnostics: Use and assessment of clinical laboratory results. 1st ed. Frankfurt: TH-Books Verlagsgesellschaft $\mathrm{mbH}$; 1998.

77. Olde B, Leeb-Lundberg LM. GPR30/GPER1: searching for a role in estrogen physiology. Trends Endocrinol Metab 2009;20:409-16. http://dx.doi.org/10.1016/j. tem.2009.04.006. 
78. Cicatiello L, Mutarelli M, Grober OM, Paris O, Ferraro $L$, Ravo $M$, et al. Estrogen receptor alpha controls a gene network in luminal-like breast cancer cells comprising multiple transcription factors and microRNAs. Am J Pathol 2010;176:2113-30. http://dx.doi.org/10.2353/ ajpath.2010.090837.

79. Ferraro L, Ravo M, Nassa G, Tarallo R, De Filippo MR, Giurato $G$, et al. Effects of oestrogen on microRNA expression in hormone-responsive breast cancer cells. Horm Cancer 2012;3:65-78. http://dx.doi.org/10.1007/s12672-012-0102-1.

80. Pinho FG, Frampton AE, Nunes J, Krell J, Alshaker H, Jacob J, et al. Downregulation of microRNA-515-5p by the estrogen receptor modulates sphingosine kinase 1 and breast cancer cell proliferation. Cancer Res 2013;73:5936-48. http:// dx.doi.org/10.1158/0008-5472.CAN-13-0158.

81. Lee YM, Lee JY, Ho CC, Hong QS, Yu SL, Tzeng CR, et al. miRNA-34b as a tumor suppressor in estrogen-dependent growth of breast cancer cells. Breast Cancer Res 2011;13:R116. http://dx.doi.org/10.1186/bcr3059.

82. Yu X, Zhang X, Dhakal IB, Beggs M, Kadlubar S, Luo D. Induction of cell proliferation and survival genes by estradiol-repressed microRNAs in breast cancer cells. BMC Cancer 2012;12:29. http://dx.doi.org/10.1186/1471-2407-12-29.

83. Yamagata K, Fujiyama S, Ito S, Ueda T, Murata T, Naitou M, et al. Maturation of microRNA is hormonally regulated by a nuclear receptor. Mol Cell 2009;36:340-7. http://dx.doi. org/10.1016/j.molcel.2009.08.017.

84. Di Leva G, Gasparini P, Piovan C, Ngankeu A, Garofalo M, Taccioli $C$, et al. MicroRNA cluster 221-222 and estrogen receptor alpha interactions in breast cancer. J Natl Cancer Inst 2010;102:706-21. http://dx.doi.org/10.1093/jnci/ djq102.

85. Qian P, Zuo Z, Wu Z, Meng X, Li G, Zhang W, et al. Pivotal role of reduced let-7g expression in breast cancer invasion and metastasis. Cancer Res 2011;71:6463-74. http://dx.doi. org/10.1158/0008-5472.CAN-11-1322.

86. Kim K, Madak-Erdogan Z, Ventrella R, Katzenellenbogen BS. A MicroRNA196a2* and TP63 circuit regulated by estrogen receptor-alpha and ERK2 that controls breast cancer proliferation and invasiveness properties. Horm Cancer 2013;4:7891. http://dx.doi.org/10.1007/s12672-012-0129-3.

87. Nagpal N, Ahmad HM, Molparia B, Kulshreshtha R. MicroR$N A-191$, an estrogen-responsive microRNA, functions as an oncogenic regulator in human breast cancer. Carcinogenesis 2013;34:1889-99. http://dx.doi.org/10.1093/carcin/ bgt107.

88. He YQ, Sheng JQ, Ling $X L, F u L$, Jin $P$, Yen $L$, et al. Estradiol regulates miR-135b and mismatch repair gene expressions via estrogen receptor-beta in colorectal cells. Exp Mol Med 2012;44:723-32. http://dx.doi.org/10.3858/ emm.2012.44.12.079.
89. Queiros AM, Eschen C, Fliegner D, Kararigas $G$, Dworatzek $E$, Westphal $C$, et al. Sex- and estrogen-dependent regulation of a miRNA network in the healthy and hypertrophied heart. Int J Cardiol 2013;169:331-8. http://dx.doi. org/10.1016/j.ijcard.2013.09.002.

90. Nothnick WB, Healy C. Estrogen induces distinct patterns of microRNA expression within the mouse uterus. Reprod Sci 2010;17:987-94. http://dx.doi. org/10.1177/1933719110377472.

91. Dai R, Phillips RA, Zhang Y, Khan D, Crasta O, Ahmed SA. Suppression of LPS-induced Interferon-gamma and nitric oxide in splenic lymphocytes by select estrogen-regulated microRNAs: a novel mechanism of immune modulation. Blood 2008;112:4591-7. http://dx.doi.org/10.1182/blood2008-04-152488.

92. Kong $X, X u X$, Yan Y, Guo F, Li J, Hu Y, et al. Estrogen regulates the tumour suppressor miRNA-30c and its target gene, MTA-1, in endometrial cancer. PLoS One 2014;9:e90810. http://dx.doi.org/10.1371/journal.pone.0090810.

93. Bhat-Nakshatri P, Wang G, Collins NR, Thomson MJ, Geistlinger TR, Carroll JS, et al. Estradiol-regulated microRNAs control estradiol response in breast cancer cells. Nucleic Acids Res 2009;37:4850-61. http://dx.doi.org/10.1093/nar/ gkp500.

94. Masuda M, Miki Y, Hata S, Takagi K, Sakurai M, Ono K, et al. An induction of microRNA, miR-7 through estrogen treatment in breast carcinoma. J Transl Med 2012;10:S2. http:// dx.doi.org/10.1186/1479-5876-10-S1-S2.

95. Zhang C, Zhao J, Deng H. 17beta-estradiol up-regulates miR-155 expression and reduces TP53INP1 expression in MCF-7 breast cancer cells. Mol Cell Biochem 2013;379:20111. http://dx.doi.org/10.1007/s11010-013-1642-6.

96. Wang G, Wang $Y$, Shen $C$, Huang YW, Huang K, Huang $\mathrm{TH}$, et al. RNA polymerase II binding patterns reveal genomic regions involved in microRNA gene regulation. PLOS One 2010;5:e13798. http://dx.doi.org/10.1371/journal.pone.0013798.

97. Zhang $R$, He $Y$, Zhang $X$, Xing $B$, Sheng $Y$, Lu H, et al. Estrogen receptor-regulated microRNAs contribute to the $B C L 2 /$ $B A X$ imbalance in endometrial adenocarcinoma and precancerous lesions. Cancer Lett 2012;314:155-65. http:// dx.doi.org/10.1016/j.canlet.2011.09.027.

98. Cochrane DR, Cittelly DM, Howe EN, Spoelstra NS, McKinsey EL, LaPara K, et al. MicroRNAs link estrogen receptor alpha status and Dicer levels in breast cancer. Horm Cancer 2010;1:306-19. http://dx.doi.org/10.1007/s12672-0100043-5. 